\title{
ER- $\alpha 36$, a novel isoform of ER- $\alpha 66$, is commonly over-expressed in apocrine and adenoid cystic carcinomas of the breast
}

\author{
Semir Vranic, ${ }^{1,2}$ Zoran Gatalica, ${ }^{1}$ Hao Deng, ${ }^{3}$ Snjezana Frkovic-Grazio, ${ }^{4}$ Lisa M J Lee, ${ }^{1,5}$ \\ Olga Gurjeva, ${ }^{6}$ Zhao-Yi Wang ${ }^{7}$
}

'Department of Pathology, Creighton University Medical Center, Omaha, Nebraska, USA 2Department of Pathology, Clinical Center of the University of Sarajevo, Sarajevo, Bosnia and Herzegovina

${ }^{3}$ Department of Pathology and Pathophysiology, School of Medicine, Jianghan University, Wuhan, China

${ }^{4}$ Department of Pathology, Institute of Oncology, Ljubljana, Slovenia

${ }^{5}$ Division of Anatomy, College of Medicine, The Ohio State University, Columbus, Ohio, USA ${ }^{6}$ Emergency Cardiology Department, Ukrainian Strazhesko Institute of Cardiology, Kiev, Ukraine ${ }^{7}$ Department of Medical Microbiology and Immunology, Creighton University Medical School, Omaha, Nebraska, USA

\section{Correspondence to}

Semir Vranic, Department of Pathology, Clinical Center of the University of Sarajevo,

BA-71000 Sarajevo, Bosnia and Herzegovina;

semir.vranic@gmail.com

Preliminary results were in part presented at the 97th Annual Meeting of the United States and Canadian Academy of Pathology, Denver, Colorado, USA in March 2008, and the 31 st Annual San Antonio Breast Cancer Symposium, in December 2008.

Accepted 7 October 2010 Published Online First

2 November 2010

\section{ABSTRACT}

Background ER- $\alpha 36$ is a novel $36 \mathrm{kDa}$ isoform of the full-length oestrogen receptor alpha (ER- $\alpha 66)$. ER- $\alpha 36$ primarily localises to the cytoplasm and the plasma membrane, and responds to membrane-initiated oestrogen and antioestrogen signalling pathways.

Aim To examine the expression of ER- $\alpha 36$ in apocrine and adenoid cystic carcinoma of the breast, both of which are consistently ER- $\alpha 66$ negative and currently lack effective targeted therapeutic options.

Methods 19 pure apocrine carcinomas (17 invasive and two in-situ carcinomas) and 11 adenoid cystic carcinomas of the breast were evaluated for ER- $\alpha 36$ expression, along with expressions of ER- $\alpha 66$, progesterone receptor (PR) and androgen receptor (AR) using immunohistochemical methods.

Results All pure apocrine carcinomas showed a characteristic steroid receptor expression profile (ER- $\alpha 66$ and PR negative, AR strongly positive). ER- $\alpha 36$ expression was detected in 18/19 pure apocrine carcinomas $(94.7 \%, 95 \% \mathrm{Cl} 75.1$ to 98.7$)$ in predominantly membranous and cytoplasmic distribution. When positive, pure apocrine carcinomas uniformly (100\% of cells) expressed ER- $\alpha 36$. All adenoid cystic carcinomas were uniformly negative for all three classic steroid receptors, but ER- $\alpha 36$ was detected in 8/11 cases $(72.7 \%, 95 \% \mathrm{Cl} 42.8$ to 90$)$ with the similar subcellular pattern of expression as in the pure apocrine carcinomas. When positive, adenoid cystic carcinomas expressed ER- $\alpha 36$ in the majority of cells (average 76\%). Conclusion ER- $\alpha 36$, a novel isoform of ER- $\alpha 66$, is frequently over-expressed in apocrine and adenoid cystic carcinomas of the breast. These results indicate a potential for a novel targeted treatment in these cancers.

\section{INTRODUCTION}

Oestrogen receptor alpha (ER- $\alpha$ ) expression in breast cancer is the most important predictor of antioestrogen therapy. ${ }^{1}$ Approximately $75 \%$ of all breast carcinomas are ER- $\alpha$ positive, which is a good predictor of the treatment response. ${ }^{2-4}$ Current immunohistochemical methods use antibodies against the full-length receptor protein (ER- $\alpha 66$, see figure 1), but there are at least three different isoforms of ER- $\alpha 66$ described in humans. Two isoforms have been detected in breast cancers. ${ }^{56}$ These are ER- $\alpha 46$ and the novel isoform, ER- $\alpha 36$ which we recently identified and cloned. ${ }^{7} 8$ They are generated through multiple promoter usage or alternative splicing. ${ }^{5}$ Although most steroid hormone receptors primarily localise in the nuclei, additional oestrogen receptors have been reported to exist in the cytoplasm and on the plasma membrane. ${ }^{3}$

The novel $36 \mathrm{kDa}$ isoform ER- $\alpha 36$ lacks the transcriptional activation domains found in ER-a66. The DNA-binding domain, dimerisation, partial ligand-binding domains as well as three myristoylation sites near the $\mathrm{N}$-terminus are retained in ER- $\alpha 36 .^{7}{ }^{8}$ While ER- $\alpha 66$ is predominantly detected in the cell nucleus, ER- $\alpha 36$ mainly localises to the cytoplasm and on the plasma membrane. ${ }^{78}$ ER-a36 has been shown to transduce the membrane-initiated steroid signalling (MISS) cascade, and function as a dominant-negative effector of oestrogen-dependent and independent transactivation mediated by ER- $\alpha 66{ }^{7}$ We have recently demonstrated the expression of ER- $\alpha 36$ in both ER- $\alpha 66$ positive (MCF-7) and negative breast cancer cell lines (MDA-MB-231), as well as in a proportion of invasive breast carcinomas of no special type. $^{89}$

In this study, we focused on adenoid cystic carcinoma (ACC) and pure apocrine carcinomas (PAC), two special types of breast carcinomas that are characteristically negative for ER- $\alpha 66,{ }^{10-12}$ and showed that the majority of them express ER- $\alpha 36$ protein.

\section{MATERIALS AND METHODS}

\section{Breast tissue samples}

Formalin-fixed, paraffin-embedded tissues (11 adenoid cystic carcinomas and 19 apocrine carcinomas) were selected from the files of the Departments of Pathology at Creighton University Medical Center (Omaha, Nebraska, USA), the Institute of Oncology Ljubljana (Slovenia), Thomas Jefferson University Hospital (Philadelphia, Pennsylvania, USA) and Kansas University Medical Center (Kansas City, Kansas, USA), after the approval of the Institutional Review Board of Creighton University School of Medicine. None of the 30 patients included in this study had received neoadjuvant therapy.

\section{Immunohistochemistry}

Immunohistochemical assays for ER- $\alpha 66$ (clone 6F11, Ventana Medical Systems, Tucson, Arizona, USA), progesterone receptor (PR; clone 16, Ventana Medical Systems), androgen receptor (AR; clone AR441, DakoCytomation, Carpinteria, California, USA), epidermal growth factor receptor (EGFR; 

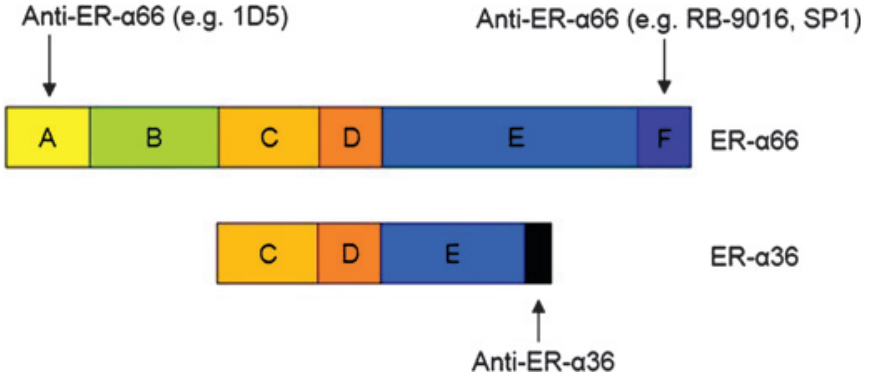

Figure 1 Domain structures of oestrogen receptor (ER)- $\alpha 66$ and ER- $\alpha 36$. Arrows indicate the specific antibodies and their corresponding epitopes.

(DAKO EGFR PharmDX diagnostic kit; DakoCytomation) and Her-2/neu (Clone CB11, Ventana Medical Systems) expression were previously performed as a part of clinical evaluation. The expression of ER- $\alpha 66, \mathrm{PR}$ and AR (the percentage of cells with the nuclear staining), and EGFR and Her-2/neu (the extent and the intensity of the membranous staining) were measured on an automated cellular imaging system (ACIS, ChromaVision Medical Systems, San Juan Capistrano, California, USA). The results of ER- $\alpha 66, \mathrm{PR}, \mathrm{AR}, \mathrm{EGFR}$ and Her-2/neu expression for both cohorts have recently been reported. ${ }^{11} 12$

Antibody used for the detection of ER- $\alpha 36$ was custom-made by Alpha Diagnostic International (San Antonio, Texas, USA); it was raised against the 20 unique amino acids at the C-terminal of ER- $\alpha 36 .^{89}$ Immunohistochemical staining with this ER- $\alpha 36$ specific antibody was performed using the rabbit ImmunoCruz Staining System (Santa Cruz, sc-2051, California, USA) according to the manufacturer's instructions. Briefly, slides with $5 \mu \mathrm{m}$ thick formalin-fixed paraffin-embedded tissue sections were deparaffinised and hydrated in sequential treatment of xylene, ethanol and water. Citrate buffer $(0.01 \mathrm{M}$ citric acid, $\mathrm{pH}$ 8.0) was used to retrieve epitopes in a pressure cooker. Endogenous peroxidase activity was quenched with $3 \% \mathrm{H}_{2} \mathrm{O}_{2}$ before anti-ER- $\alpha 36$ (at 1:100 dilution) antibody was applied. Biotinylated secondary antibody and streptavidin-horseradish peroxidase were added subsequently, and 3,3'-diaminobenzidine tetrahydrochloride was used as substrate for chromogenic visualisation before counterstaining with haematoxylin. The extent and cellular distribution of staining was evaluated by two investigators on a double-headed microscope. The subcellular localisation and percentage of positive cells was recorded.

For ER $\alpha-36$ expression, only the membranous/cytoplasmic pattern of staining was considered specific. 89 Weak $(1+)$ intensity was defined as faint and incomplete membrane positivity. Moderate $(2+)$ intensity and strong $(3+)$ staining were both varying degrees of circumferential staining of membranes and the cytoplasm. The tumour was considered positive if a proportion of stained cells exceeded $1 \%$ at any intensity. ${ }^{9}$

\section{Statistical analysis}

To access the differences between proportions, two-sided Fisher's exact tests were used; $\alpha$ was set at a level of 0.05 . The kappa statistic was applied to determine the consistency among the tests and 95\% CIs are given around the estimates. Statistical analyses were carried out using SPSS V.17.0.

\section{RESULTS}

\section{Patient characteristics}

The mean age was 62 years (range 53-71 years) for patients diagnosed with ACC and 74 years for PAC (range 63-90 years).

\section{Special breast cancer subtype characterisation}

All PACs (including two in-situ carcinomas) were characteristically ER- $\alpha 66$ negative, PR negative and AR positive. ${ }^{11} \mathrm{Her}-2 /$ neu over-expression $(3+)$ was observed in $10 / 19$ cases $(52.6 \%, 95 \%$ CI 31.53 to 72.80); EGFR expression was observed in $17 / 19$ (89.5\%, 95\% CI 68.30 to 96.79$)$. Of the two apocrine carcinomas in-situ, one over-expressed Her-2/neu (score $3+$ ) and the other was positive for EGFR (score $3+$ ).

All ACC samples exhibited a characteristic triple-negative breast cancer profile (ER- $\alpha 66$ negative, PR negative, Her-2/neu negative). EGFR was detected in $7 / 11(63.6 \%, 95 \%$ CI 34.89 to 84.83) ACCs, as reported recently. ${ }^{12}$

Table 1 summarises the immunohistochemical characteristics of these two cancer types.

\section{ER- $\alpha 36$ protein expression in PAC and ACC}

ER-a36 protein was detected in 18/19 PACs $(94.7 \%, 95 \% \mathrm{CI}$ 75.13 to 98.77$)$ and in 8/11 cases of ACC (72.7\%, 95\% CI 42.81 to 90.08$)$. Moderate to strong membranous and cytoplasmic expression (figure 2C,D) was seen in both cancer types. The average percentage of ER-a36 positive cells was 100\% for PAC and $76.2 \%$ for ACC. Nuclear staining was absent in all but one case of PAC, which exhibited both nuclear and cytoplasmic/ membrane distribution of the ER- $\alpha 36$

We also analysed our cases for the co-expression of ER- $\alpha 36$ with EGFR and Her-2/neu proteins because of reported interactions between membrane steroid receptors and growth factors with tyrosine kinase activity. ${ }^{13}$ Co-expression of ER- $\alpha 36$ and EGFR was observed in 16 cases of PAC and 7 cases of ACC. Although co-expression of ER- $\alpha 36$ and EGFR in both types of breast carcinomas was statistically significant $(p=0.018)$, the measure of agreement was only marginally convincing $(\kappa=0.52$, $95 \%$ CI 0.12 to 0.93 ) (table 2). Co-expression of ER- $\alpha 36$ and Her$2 /$ neu however was not found to have a significant relationship $(\mathrm{p}=1.00)$

Adjacent normal breast tissue (ductal epithelium) was negative or showed reduced expression of ER- $\alpha 36$ in comparison to expression in the malignant epithelium.

\section{DISCUSSION}

ER-a66 expression is routinely evaluated by immunohistochemistry in all breast cancers since it has been shown to play a pivotal role in $^{2-4}$ patient treatment and outcome. Approximately $75 \%$ of all breast carcinomas are regarded as ER$\alpha 66$ positive, and are thus amenable to targeted therapy with antioestrogens. $^{2-4}$

The ER- $\alpha$ gene (ESR1) is composed of six functional domains encoded by eight exons that commonly produce a $66.2 \mathrm{kDa}$ protein $(E R-\alpha 66) .{ }^{5}$ Numerous ER- $\alpha$ mRNA transcript isoforms of

Table 1 Immunohistochemical characteristics of 30 breast samples

\begin{tabular}{llllll}
\hline $\begin{array}{l}\text { Tumour } \\
\text { type }\end{array}$ & $\begin{array}{l}\text { ER- } \alpha \mathbf{6 6} \\
{[\mathbf{9 5 \%} \mathbf{~ C l}]}\end{array}$ & $\begin{array}{l}\text { PR } \\
{[\mathbf{9 5 \%} \text { Cl] }]}\end{array}$ & $\begin{array}{l}\text { Her-2/neu* } \\
{[\mathbf{9 5 \%} \mathbf{~ C l}]}\end{array}$ & $\begin{array}{l}\text { EGFR } \dagger \\
{[\mathbf{9 5 \%} \mathbf{~ C l}]}\end{array}$ & $\begin{array}{l}\text { ER- } \alpha \mathbf{3 6} \\
{[\mathbf{9 5 \%} \mathbf{~ C l}]}\end{array}$ \\
\hline PAC & $0 / 19(0 \%)$ & $0 / 19(0 \%)$ & $10 / 19(52.6 \%)$ & $17 / 19(89.5 \%)$ & $18 / 19(94.7 \%)$ \\
& {$[0.13$ to } & {$[0.13$ to } & {$[31.53$ to } & {$[68.30$ to } & {$[75.13$ to } \\
& $16.84]$ & $16.84]$ & $72.80]$ & $96.79]$ & $98.77]$ \\
ACC & $0 / 11(0 \%)$ & $0 / 11(0 \%)$ & $0 / 11(0 \%)$ & $7 / 11(63.6 \%)$ & $8 / 11(72.7 \%)$ \\
& {$[0.21$ to } & {$[0.21$ to } & {$[0.21$ to } & {$[34.89$ to 84.83$]$} & {$[42.81$ to 90.08$]$} \\
& $26.46]$ & $26.46]$ & $26.46]$ & &
\end{tabular}

*Her-2/neu protein positivity defined as $3+$ score by immunohistochemistry. †EGFR protein positivity defined as a membranous staining if a proportion of stained cells exceeded $1 \%$ at any intensity.

$E R$, oestrogen receptor; PR, progesterone receptor; EGFR, epidermal growth factor receptor $\mathrm{PAC}$, pure apocrine carcinoma; ACC, adenoid cystic carcinoma. 
Figure 2 Representative H\&E slides of: (A) a case of adenoid cystic carcinoma of the breast; $(B)$ a pure apocrine carcinoma of the breast; (C) immunohistochemical staining of the tissue samples for ER- $\alpha 36$, demonstrating strong membrane and cytoplasmic staining in an adenoid cystic carcinoma; (D) a pure apocrine carcinoma of the breast.
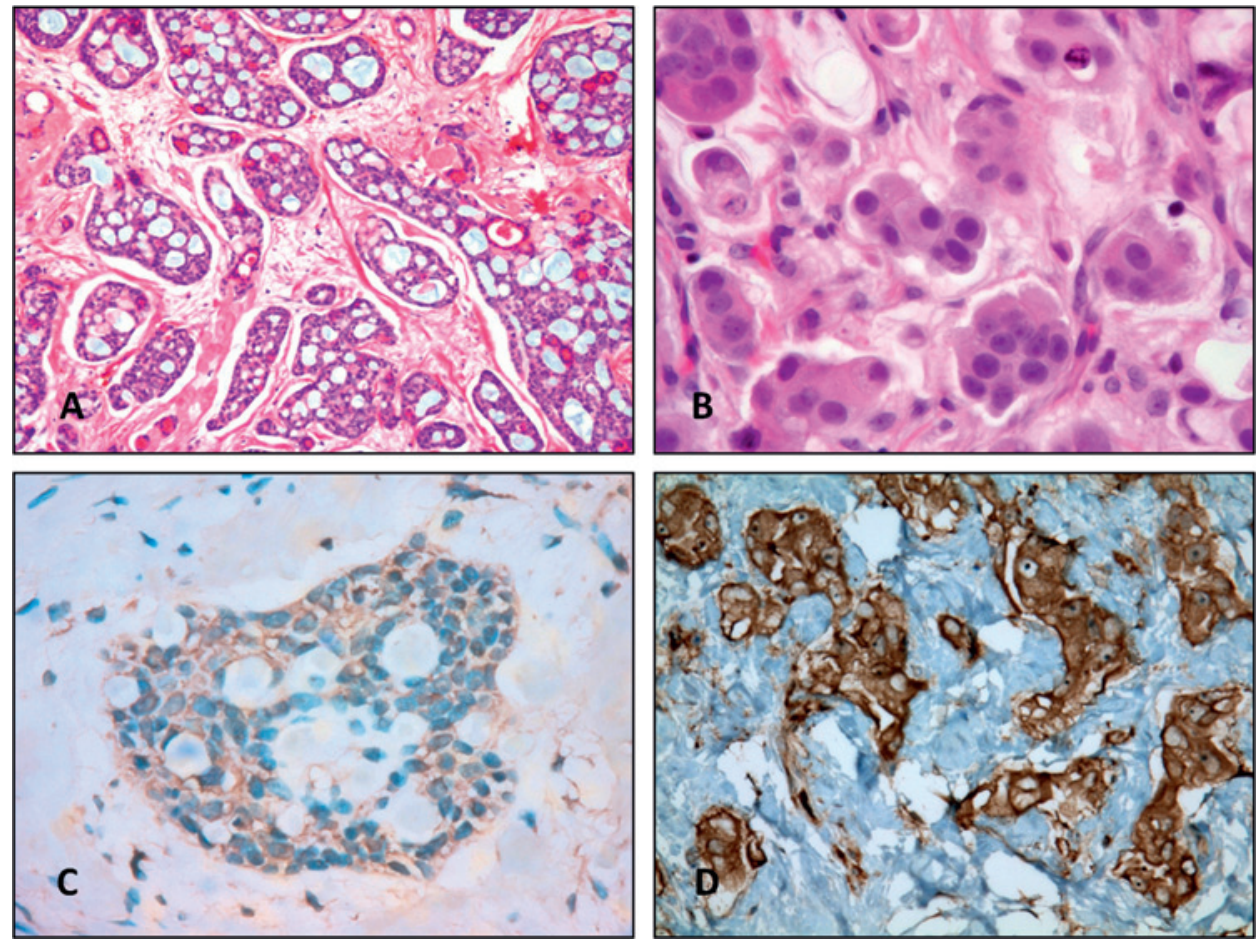

the gene have been described, ${ }^{6}$ and are generated through alternative splicing or promoter usage. ${ }^{5}$ Several isoforms of the ER- $\alpha$ protein have been isolated in humans, including ER- $\alpha 36$, recently identified and cloned by our group. ${ }^{7-9}$ This novel ER- $\alpha$ isoform is a product of a transcript initiated from a previously unidentified promoter in the first intron of the ER- $\alpha 66$ gene and is identical to the ER- $\alpha 66$ encoded by exons 2-6 of the ER- $\alpha 66$ gene, resulting in a smaller, $36 \mathrm{kDa}$ protein (ER-a36). ${ }^{7} 8$ In the experimental cell models of breast cancer, it served as a membrane-based oestrogen receptor mediating MISS and as a dominant-negative modulator of ER- $\alpha 66$ mediated transcription activity. ${ }^{7}$ We have previously reported that ER- $\alpha 36$ is frequently detected in invasive breast carcinomas of no special type, ${ }^{9}$ and that it may also play a role in prognosis. ${ }^{14}$

Our current study showed that ER- $\alpha 36$ was also frequently expressed in pure apocrine carcinoma and adenoid cystic carcinomas, which are characteristically negative for the full length ER- $\alpha 66^{10-12}$

ER- $\alpha 36$ was over-expressed in the neoplastic cells in comparison to adjacent normal ductal epithelia, emphasising its role in tumour progression. It was almost exclusively expressed on the plasma membrane and in the cytoplasm; nuclear staining was observed in only one case of PAC. These results are in accordance with our recently published experimental and clinical investigations in the breast cancer cell lines and human breast cancers, where ER-a36 expression was localised primarily to the plasma membrane $(50 \%)$ and the cytoplasm (40\%), with little or no nuclear staining (up to $10 \%$ ). ${ }^{7-9}$ Subcellular localisation of ER- $\alpha 36$ is in sharp contrast to the nuclear localisation of the full-length ER- $\alpha 66$. Nuclear expression of ER- $\alpha 66$ is considered a diagnostic hallmark for 'ER-positive' tumours, although functionally active extranuclear pools of ER- $\alpha 66$ exist. ${ }^{4}{ }^{15}$ Cytoplasmic ER- $\alpha 66$ expression can be observed in breast cancer cells after long-term treatment with tamoxifen, coinciding with resistance to the drug. ${ }^{16}$ Shi et al indicated the importance of ER- $\alpha 36$ in development of endocrine resistance in a subgroup of invasive breast carcinomas that exhibit co-expression of ER- $\alpha 66$ and ER- $\alpha 36 .{ }^{14}$
Identification of the ER- $\alpha 36$ isoform in PAC explains reported discrepancies between mRNA detection and negative ER protein expression. Bratthauer et al reported that ER mRNA was detectable in all cases of apocrine carcinomas despite a complete absence of ER protein using the commercially available immunohistochemical assay against ER- $\alpha 66 .{ }^{17}$ The authors used RT-PCR amplification of ER mRNA using primers that covered the first and second exon of the ER- $\alpha 66$ messenger RNA, and concluded that the immunohistochemical absence of ER was not a consequence of an abnormal transcript but did not elaborate. We hypothesise that detectable mRNA in apocrine carcinomas might well be one of the alternatively spliced isoforms of ER- $\alpha$ including currently studied ER- $\alpha 36$. ER- $\alpha 36$ protein could not have been detected due to the lack of antibody specificity; the ER- $\alpha 66$ antibody used in their study (clone CC4-5, Novocastra Laboratories) recognises the N-terminal of the ER- $\alpha 66$ which is not shared between the full-length and ER- $\alpha 36$ isoform (see figure 1). ${ }^{18}$ Other commonly used commercial antibodies (eg, 1D5, SP1, RB-9016) recognise the epitopes located on either the $\mathrm{N}$ - or $\mathrm{C}$-terminal of the $E R$ - $\alpha$ gene which are not represented in either ER- $\alpha 36$ or ER- $\alpha 46$ isoforms. ${ }^{5}$

Functional importance of ER- $\alpha 36$ is reportedly related to the non-genomic (non-classic) ER activities, among which activation of the mitogen-activated protein kinase (MAPK/ERK) signalling pathway plays a major role. ${ }^{8}$ The MAPK/ERK signalling pathway is activated in response to both oestrogens

Table 2 Relationship between oestrogen receptor (ER)$\alpha 36$ and epidermal growth factor receptor (EGFR) expression

\begin{tabular}{lllcc}
\hline & & EGFR & & \\
\cline { 3 - 4 } Variable & & Negative & Positive & Total \\
\hline ER- $\alpha 36$ & Negative & 3 & 1 & 4 \\
& Positive & 3 & 23 & 26 \\
Total & & 6 & 24 & 30 \\
\hline
\end{tabular}

$\mathrm{p}=0.018, \kappa=0.52(95 \% \mathrm{Cl} 0.12$ to 0.93$)$ 


\section{Take-home messages}

Adenoid cystic carcinoma and pure apocrine carcinoma are two rare, special types of breast cancer characteristically negative for oestrogen receptor- $\alpha 66$ (ER- $\alpha 66)$.

- The novel $36 \mathrm{kDa}$ isoform of ER- $\alpha 66$ (ER- $\alpha 36$ ) lacks the transcriptional activation domains of ER- $\alpha 66$ and predominantly localises to the cytoplasm and on the cell membrane. It mediates non-classic (non-genomic) oestrogen signalling.

- ER- $\alpha 36$ is commonly over-expressed in adenoid cystic carcinoma and pure apocrine carcinoma of the breast, which may indicate a potential for novel treatment strategies in these cancers.

(eg, 17 $\beta$-oestradiol) and antioestrogens (eg, tamoxifen) which might be of particular importance for ER- $\alpha 66$ negative breast carcinomas since this subgroup might still respond to antioestrogen based therapy. 8 Previous experiments demonstrated that the antioestrogens induce a stronger and a more prolonged activation of the MAPK/ERK signalling pathway than the oestrogens. $^{8}$

Our study also revealed a significant relationship between ER- $\alpha 36$ and EGFR expression, indicating a close interaction of the two membrane-initiated signalling. ${ }^{13} 19$ Although Her-2/neu can also be actively involved in membrane-initiated steroid signalling, we could not identify a significant correlation between ER- $\alpha 36$ and Her-2/neu in our study.

In summary, membranous ER- $\alpha 36$ is over-expressed in breast tumours showing a complete absence of the full-length ER- $\alpha 66$ protein, indicating a potential for targeting the non-genomic growth signalling.

Acknowledgements We thank Drs Ossama Tawfik, Juan Palazzo, Janez Lamovec and Eduardo Eyzaguirre for contributing cases for the study and Dr Fadila Serdarević for statistical expertise. We also acknowledge Mr Mirza Bašić for technical assistance.

Funding SV was a research fellow at Creighton University Medical Center, Omaha, Nebraska, USA, and had been supported by a UICC American Cancer Society Beginning Investigators Fellowship (ACSBI) (ACS/08/004) funded by the American Cancer Society.

Competing interests None declared.
Ethics approval This study was conducted with the approval of the Institutional Review Board of Creighton University School of Medicine.

Provenance and peer review Not commissioned; externally peer reviewed.

\section{REFERENCES}

1. Katzenellenbogen BS, Frasor J. Therapeutic targeting in the estrogen receptor hormonal pathway. Semin Oncol 2004;31:28-38.

2. Nadji M, Gomez-Fernandez C, Ganjei-Azar P, et al. Immunohistochemistry of estrogen and progesterone receptors reconsidered: experience with 5,993 breast cancers. Am J Clin Pathol 2005;123:21-7.

3. Levin ER, Pietras RJ. Estrogen receptors outside the nucleus in breast cancer. Breast Cancer Res Treat 2008;108:351-61.

4. Allred DC. Issues and updates: evaluating estrogen receptor- $\alpha$, progesterone receptor, and HER2 in breast cancer. Mod Pathol 2010;23:S52-9.

5. Bretschneider N. Regulation of estrogen responsive genes by the human Estrogen receptor alpha $(E R \alpha)$. Heidelberg: Combined Faculties for the Natural Sciences and for Mathematics of the Ruperto Carola University of Heidelberg, 2007 (dissertation)

6. Hirata S, Shoda T, Kato J, et al. Isoform/variant mRNAs for sex steroid hormone receptors in humans. Trends Endocrinol Metab 2003;14:124-9.

7. Wang ZY, Zhang XT, Shen P, et al. Identification, cloning, and expression of human estrogen receptor-alpha36, a novel variant of human estrogen receptor-alpha66. Biochem Biophys Res Commun 2005;336:1023-7.

8. Wang ZY, Zhang XT, Shen P, et al. A variant of estrogen receptor-alpha, hERalpha36: transduction of estrogen- and antiestrogen-dependent membrane-initiated mitogenic signaling. Proc Natl Acad Sci USA 2006;103:9063-8.

9. Lee LM, Cao J, Deng H, et al. ER-alpha36, a novel variant of ER-alpha, is expressed in ER-positive and -negative human breast carcinomas. Anticancer Res 2008;28:479-83

10. Weigelt B, Horlings HM, Kreike B, et al. Refinement of breast cancer classification by molecular characterization of histological special types. J Pathol 2008;216:141-50.

11. Vranic S, Tawfik 0, Palazzo J, et al. EGFR and HER-2/neu expression in invasive apocrine carcinoma of the breast. Mod Pathol 2010;23:644-53.

12. Vranic S, Frkovic-Grazio S, Lamovec J, et al. Adenoid cystic carcinomas of the breast have low topo $\| \alpha$ expression but frequently overexpress EGFR protein without EGFR gene amplification. Hum Pathol 2010;41:1617-23.

13. Kampa M, Pelekanou V, Castanas E, et al. Membrane-initiated steroid action in breast and prostate cancer. Steroids 2008;73:953-60.

14. Shi L, Dong B, Li Z, et al. Expression of ER-\{alpha\}36, a novel variant of estrogen receptor $\{$ alpha\}, and resistance to tamoxifen treatment in breast cancer. J Clin Oncol 2009;27:3423-9.

15. Fowler AM, Santen RJ, Allred DC. "Dwarf" estrogen receptor in breast cancer and resistance to tamoxifen. J Clin Oncol 2009;27:3413-15.

16. Fan $\mathbf{P}$, Wang JP, Santen RJ, et al. Long-term treatment with tamoxifen facilitates translocation of estrogen receptor alpha out of the nucleus and enhances its interaction with EGFR in MCF-7 breast cancer cells. Cancer Res 2007:67:1352-60.

17. Bratthauer GL, Lininger RA, Man YG, et al. Androgen and estrogen receptor mRNA status in apocrine carcinomas. Diagn Mol Pathol 2002;11:113-18.

18. Tavassoli FA, Purcell CA, Bratthauer GL, et al. Androgen receptor expression along with loss of bcl-2, ER, and PR expression in benign and malignant apocrine lesions of the breast. Implications for therapy. Breast J 1996;2:261-9.

19. Zhang XT, Kang LG, Ding L. A positive feedback loop of ER- $\alpha 36 /$ EGFR promotes malignant growth of ER-negative breast cancer cells. Oncogene Published Online First: 11 October 2010. doi:10.1038/onc.2010.458. 